University of Rhode Island

DigitalCommons@URI

2016

\title{
Does Global Market Integration Weaken Opinion-Policy Congruence in the American States?
}

\author{
Bret Anderson \\ Brian S. Krueger \\ University of Rhode Island, bkrueger@uri.edu \\ Ping $\mathrm{Xu}$ \\ University of Rhode Island, pingxu@uri.edu
}

Follow this and additional works at: https://digitalcommons.uri.edu/psc_facpubs

The University of Rhode Island Faculty have made this article openly available.

Please let us know how Open Access to this research benefits you.

This is a pre-publication author manuscript of the final, published article.

Terms of Use

This article is made available under the terms and conditions applicable towards Open Access

Policy Articles, as set forth in our Terms of Use.

\section{Citation/Publisher Attribution}

Anderson, B. , Krueger, B. S. and Xu, P. (2016), Does Global Market Integration Weaken Opinion-Policy Congruence in the American States?. Politics and Policy, 44: 677-711. doi:10.1111/polp.12167 Available at: http://dx.doi.org/10.1111/polp.12167 


\title{
Does Global Market Integration Weaken
}

\section{Opinion-Policy Congruence in the American States? ${ }^{1}$}

\author{
Bret Anderson \\ Assistant Professor \\ Department of Economics \\ University of Rhode Island \\ Email: bkrueger@uri.edu
}

Brian S. Krueger

Professor

Department of Political Science

University of Rhode Island

Email: bkrueger@uri.edu

Ping $\mathrm{Xu}$

Assistant Professor

Department of Political Science and

University of Rhode Island

Email: pingxu@uri.edu 


\begin{abstract}
Theories of economic globalization suggest that public opinion-public policy congruence should be affected by states' degree of integration with international markets. With as much attention researchers have given to the opinion-policy linkage in the American states, it is surprising that this literature has neglected these well-known globalization frameworks. We take advantage of the wide variation in US states' integration in global markets, public policies, and political orientations of citizens, to assess whether global market integration depresses the association between citizen opinion and public policies. Using three decades of state-level data, our results suggest that high global market integration does not attenuate the relationship between state opinion and state public spending. Not only does this finding run counter to the well-known policy convergence thesis, but our results also suggest that the association between opinion and policy in the American states may be strongest under conditions of high global market integration.
\end{abstract}


Because many theories assert that the quality of government, especially democracies, can in part be assessed by whether public policies mirror the public preferences, political scientists have long sought to assess the relationship between public opinion and public policy (Erikson, et al. 1993.; Dahl 1989). A positive link between opinion and policy has been demonstrated across enough diverse domains that it is even referred to as 'conventional wisdom' within parts of the discipline (see Burstein 2003, 29). ${ }^{2}$ Although the dominant view suggests a substantial opinionpolicy linkage, a group of mostly recent studies offer important critical or qualifying arguments.

Jacobs and Shapiro (2000) note that elite manipulation of public opinion, rather than responsiveness, may help explain much of the opinion-policy linkage. Others argue that many of the traditional approaches to assess opinion-policy congruence may mask the true relationship between public opinion and policy (Bartels 2008; Gilens and Page 2014). A growing number of scholars largely accept that a connection exists, but seek to identify factors that enhance or attenuate the strength of the opinion-policy linkage (Monroe 1998; Monogan 2013; Lax and Phillips 2012; Radcliff and Saiz 1995; Krueger and Mueller 2001; Jacobs and Page 2005; Gilens 2005; Flavin 2012). Overall this literature points to the need for further consideration of when and how opinion and policy are connected.

With as much attention the U.S. opinion-policy linkage has received in general over the past few decades and with the search for qualifiers enriching this debate recently, it is surprising that the literature has neglected to consider theories of economic globalization. Two of the most prominent theoretical frameworks for understanding economic globalization provide a central position for democratic responsiveness, and hence the opinion-policy connection. Additionally, much of the framing of economic globalization in the news media centers on governments disregarding their citizen's wishes in favor of global bond markets and international corporations. 
Just recently, the Greek government ignored a one-week-old citizen referendum and accepted the European Union's austerity demands and the U.S. negotiated the Trans-Pacific Partnership trade agreement in secret --without any citizen input to reject. The New York Times chronicled widespread cutting of "public services" across the American states due to revenue shortfalls caused in part by concessions made to global corporations; many U.S. state "officials said they feared that companies would move jobs overseas" if billions of dollars in special tax treatment ended (Story 2012).

The opinion-policy literature's past inattention to economic globalization is somewhat understandable. Decades ago, when the iconic studies that built the foundation of the opinionpolicy congruence literature emerged, the U.S. had among the lowest exposure to global trade as percentage of GDP compared to other OECD countries. But understanding the U.S. as a globalization outlier no longer applies, as the United States has tripled its reliance on international trade as a percentage of GDP from 1977 to 2010 (see Owen and Quinn 2014). Additionally, the diversity at the U.S. state level has long been used to examine the opinionpolicy congruence and offers a fruitful place to examine the implications of economic globalization on the opinion-policy connection because state economies have varying degrees of integration with the global marketplace. ${ }^{3}$

In this paper, we offer an initial test of whether the degree of American states' global market integration moderates the relationship between citizen opinion and government spending from 1987 to 2006. A study incorporating globalization theories not only enhances our understanding of the potential moderators of the opinion-policy linkage, but also provides a new domain to test competing views of economic globalization. The structure of the paper is as follows. In the next section, we discuss the policy convergence and room to maneuver theoretical 
frameworks and connect these competing theories to expectations about the opinion-policy linkage in the American states. Then we introduce our data and methods and present the major findings. Using three decades of state-level data, our results suggest that high global market integration does not attenuate the relationship between state opinion and state public spending, which runs counter to the well-known policy convergence thesis. Finally we offer a discussion of the implications of our results and suggest some limitations of these initial findings.

\section{Policy Convergence Theory}

Policy convergence theory ranks as the most widely recognized theory regarding the relationship between economic globalization and public policy (Mosley 2005). Convergence theory argues that high levels of integration with global markets encourage public policies that conform to corporate preferences and eventually converge. Capital mobility and competition between states to attract and retain this capital underpin the convergence logic. Mobile firms in the global market become increasingly averse to residing in regions that sustain large public sectors, which are seen to decrease work incentives, increase the costs of business operations, and ultimately reduce profit (Garrett 1998). In a highly globalized environment where capital and firms can relocate their business to the most favorable locale relatively easily, states are pressured to structure state spending in order to provide a low cost environment for corporations. ${ }^{4}$ As a result, under the pressure of "capital flight" with globalization, state policy will converge, as states race-to-the-bottom in public spending.

From this perspective, the needs of corporations in the global market dominate state spending policies. States that are highly integrated with the global market and wish to take an alternative policy track cannot do so without suffering negative economic consequences. As Waltz reminds us, “states can defy the 'herd,' but they will pay a price, usually a steep one,” as 
high spending states will encourage capital flight (Waltz 1999, 694). Because elected officials have difficulty remaining in power with economic downturns such as job losses or wage declines, states, regardless of their ideological proclivities, are predicted to converge at a low public spending bottom under pressures of economic globalization.

Garrett suggests that for convergence theory, "political autonomy, if not de jure sovereignty, is considered the primary 'casualty’ of globalization” (Garrett 1998, 788, see also Agné 2011; Habermas 1999; Dahl 1989; Held 1995). And although state political autonomy alone may not be sufficient for a strong connection between citizens’ opinions and public policy, it is a necessary condition (Agné 2011). Because the needs of the global market dominate policymaking, and citizens' views become relatively less important, the citizen opinion-public policy connection should be attenuated. ${ }^{5}$ As Piven notes about globalization in the American states, "[c]itizenship loses much of its meaning if governments cannot act on matters crucial to the economic well-being of ordinary people. In this sense, democratic rights are rolled back” (Piven 2001, 28).

\section{Room to Maneuver}

Policy convergence theory ranks as the best known framework for understanding how capital mobility affects states' ability to make policy choices reflecting public opinion. The room to maneuver approach is often seen as its chief theoretical rival. In short, the room to maneuver hypothesis suggests that, "political reactions to globalization are not entirely preprogrammed by globalization itself but also depend on domestic structures” (Genschel 2004, 632; see also Mosley 2005, 355). Indeed, the earliest work in this area by Cameron (1978) and Katzenstein (1985) shows that instead of globalization leading to a race to the bottom, it instead often triggers greater public spending because citizens increase their demands for governmental 
compensation and protections against the risks and anxieties associated with increased global market integration (Agné 2011).

Geoffrey Garrett, one of the best known empirical researchers in this area, shows through his analysis of advanced democracies that the "benefits of globalization can be reaped without undermining the economic sovereignty of nations, and without reducing the ability of citizens to choose how to distribute benefits - and the costs - of the market” (Garrett 1998, 6). Importantly, in the mostly European nations that are analyzed by Garrett, increased economic globalization typically amplifies the demands of citizens that want increased public social services and protections. For Garrett, economic globalization enhances the "political logic of voice," from the people in the area of social protections by "strengthened political incentives for governments to use the policy instruments of the state to mitigate dislocations by redistributing wealth and risk" (Garrett 1998, 789-791).

In part because the room to maneuver hypothesis is known to diverge sharply with convergence theory, and because social democratic parties in Europe have been a core focus of empirical research, room to maneuver is often associated with increases in social spending. But a close reading of the theory suggests that room to maneuver is more accurately described as states having the ability to use a variety of tools and policies to respond to the challenges associated with economic globalization. Policy option is key. Garrett is certainly aware that states can maneuver in various ways, "social democratic/left parties respond to globalization differently than center right and right parties” (Garrett 1995, 658; see also Burgoon 2001; Agné 2011). Conservatives often argue that in the face of increased economic global competition, making the state environment the most attractive to capital by cutting public spending offers the best chance for corporations and citizens alike to prosper. In other words, rather than growing 
the public sector to provide more social welfare benefits and other government services, conservatives want "supply side oriented economic policies that emphasize growth and employment" that will retain globally mobile capital in the state and by extension keep the unemployment rate low, obviating much of the need for public services (Swank 2005, 188).

This logic may be particularly efficacious in the U.S. context because welfare state legitimacy is lowest in Anglo-Liberal democracies and the U.S. in particular (Brooks and Manza 2006b; Brooks and Manza 2006a). In the U.S. small government arguments are more accepted generally, and economic globalization, with its threat of capital exit, provides a structural context that may strengthen the logic of existing conservative desires for the nature of public spending (Piven 2001). In other words, when exposed to global market competition, conservative citizenries will use the global market logic to push for reductions in public expenditures to attract and retain capital, with the hopes that this will bring a robust economy and high wage jobs.

Altogether, the room to maneuver hypothesis suggest that economic globalization should not sever the link between citizen opinion and policy. Although liberals and conservatives will approach solving the challenges associated with economic globalization differently, citizens in states that have globally integrated economies will demand that states conform to their view of how public policies should deal with the global marketplace. When highly exposed to global market pressures, states with liberal populations will demand a robust public sector to compensate for the vagaries and anxiety associated with economic globalization. Conservative citizens in highly globalized states will use the threat of capital flight and global competition to press for efficiency in the form of low public spending. Critically, room to maneuver not only suggests that liberal and conservative citizens will demand different policy outcomes, but that states will have the ability to match their public policies to various citizen preferences. 


\section{Hypotheses}

The two theoretical frameworks suggest different implications for the citizen opinionpublic policy connection in the U.S. states. In situations where public opinion generally influences public policy, we would expect the following empirical implications of the theories presented above:

\section{Convergence Hypothesis}

The relationship between state citizen ideology and state public policies should be weaker in states with high global trade compared to states with low global trade.

\section{Room to Maneuver Hypothesis}

The relationship between state citizen ideology and state public policies should not be weaker in states with high global trade compared to states with low global trade.

If the marginal effect of state citizen ideology on public policy is weaker in highly globalized states compared to lowly globalized states, then the evidence would support the convergence hypothesis. If the marginal effect of state citizen ideology on public policy is not statistically different (null) or stronger in highly globalized states compared to low globalized states, then the evidence would support the room to maneuver hypothesis. ${ }^{6}$ Although crossnational empirical studies of globalization and public policy often evaluate the independent connection between global trade and public policy, the global trade $\rightarrow$ public policy linkage is not key to evaluating our hypotheses; we are focused instead on whether high levels of global trade attenuates the citizen opinion-policy connection. Throughout the manuscript, when considering 
the hypotheses, we will compare the independent relationship between citizen opinion and public policy when states have low versus high levels of global trade.

\section{Data and Methods}

We utilize pooled cross-sectional time-series (CSTS) data from 1987 to 2006 to assess the applicability of these competing frameworks for understanding how the degree of global market integration influences the linkage between public opinion and public spending in the American states. Broadly considered, we estimate overall state government spending and state government spending on welfare as a function of state citizen opinion liberalism and its interaction with two distinct, but overlapping, measures of economic globalization at the state level: trade dependence and trade exposure (detailed below). These interactions test for any conditional effect that economic globalization may have on the public opinion-public spending linkage. This approach follows Monogan, Gray, and Lowery’s $(2009,306)$ technique for assessing whether the "effect of opinion liberalism on policy liberalism differs between initiative and noninitiative states,” except that we consider how state level global market integration conditions the association between opinion and policy. We use a fixed effects estimator with robust standard errors that includes both state and year fixed effects. We estimate the following equation of per capita state expenditures,

state expend $_{i t}=\beta_{0}+\beta_{1}$ opinion $_{i t}+\beta_{2}$ globe $_{i t}+\beta_{3}\left(\right.$ globe $\times$ opinion $_{i t}+$ control $_{i t}+\alpha_{i}+\delta_{t}+\mu_{i t}$ 
where opinion is a state $i$ 's citizen opinion liberalism in year $t$. Globe is a state's degree of global market integration, and globe $\mathrm{x}$ opinion is their interaction. Control is a vector of relevant control variables, $\alpha$ is the state fixed effects, $\delta$ is the year fixed effects, and $\mu$ is the error term. The control variables are included to account for macro conditions that influence a state's 1) ability to spend money (i.e. per capita income) and 2) the demand for public spending (i.e. unemployment rate). After we control for states' ability to spend on programs as well as the states' demand for program spending, we expect that citizens' political opinion should help predict the remaining variance in the amount of state spending, with liberal states spending more and conservative states spending less. In other words, assessing the public opinion - state spending connection only serves as a measure of congruence when the key macro level factors have been held constant. Below we detail the two expenditure measures used as dependent variables, as well as the relevant independent variables.

Considering that little consensus exists about the best way to handle cross-sectional timeseries data (Greene 2011; Baltagi, et al. 2003), we also ran a set of dynamic error correction models (ECMs) as an alternative to our fixed effect models following Banerjee, et al. (1993), De Boef (2001) and De Boef and Keele’s (2008). Details of the ECM modeling strategy, as well as the results are presented in Appendix 2. The results from the two modeling approaches are broadly consistent and suggest that while facing higher levels of globalization, the independent relationship between mass liberalism and public spending in the American states is not attenuated. Table 1 and the discussion that follows present the measurements and data sources of the variables in detail.

\section{Dependent Variables}


We use as our dependent variables two different categories of per capita government spending - overall state public expenditure and expenditures on welfare. Data on these measures are collected from State and Local Government Finance of the Census Bureau. The typical state averages approximately $\$ 3,500$ in total expenditures per person in the population and just over $\$ 700$ in per capita welfare expenditures, with each of these distributions approaching normal. We use per capita spending to distinguish between states of varying populations and to facilitate interpretation of the results. ${ }^{7}$

\section{Core Independent Variables}

State Citizen Opinion Liberalism

Because it offers a long time series and relies on citizens, rather than elite proxies, we use a voter liberalism score created by Pacheco (2011) as the measure of state voter ideology. This measure is derived from state exit polls using Multilevel Regression with Post-stratification (MRP) and represents the collective general ideological orientation of state voters. The score ranges from 0 to 100 , with higher values indicating a more liberal electorate. Overtime measures of specific policy opinion are not available; fortunately, general political ideology by far best predicts state level social spending, compared to all other policy outputs (Brace, et al. 2002, $183)^{8}$

Global Market Integration: Trade Dependence and Exposure

Because "increasing trade competition is the first component of the conventional globalization thesis” we use two distinct, but overlapping, measures to capture different aspects of global market integration (Garrett 1998, 792). The first measure is state exports as a 
percentage of Gross State Product (GSP). We refer to this measure as trade dependence and believe it to best capture the relative size of a state's exporting economy. This variable mirrors trade measures that are commonly used in cross-national studies. Krugman (2008) refers to it as a measure of how crucial trade is to an economy and also as a measure of trade importance or trade reliance. Economies with larger shares of state incomes derived from international exports are more trade dependent. Data on state-level exportation data are collected from the Foreign Trade Division of the Department of Commerce in the Census. We would have preferred using total trade (imports plus exports as a percentage of GSP) as our measure, to be consistent with the cross-national studies, but state level importation data are not available for the time series. Even so, the correlations between U.S. national-level export and total trade from 1960-2012 are over 0.9 , which suggests that our state-level export measure is highly correlated with the statelevel total trade measure.

Economic globalization is a complex process, and what a state exports matters for economic performance and how individuals experience international trade (Hausmann, et al. 2007). We therefore construct a second measure of global market integration, trade exposure, to better capture the positioning of a state's exporting economy. Trade exposure is an index of states' comparative advantage/disadvantage in particular industries weighted by an industry's position on the U.S. net exports - net import spectrum. Appendix 1 describes the construction of the trade exposure index.

The trade exposure index has several favorable qualities. First, it exploits industry-level data in order to identify a state's comparative advantage in a particular industry. In this analysis we use state data on the relative sizes of three industries: services, agriculture, and manufacturing. Second, it also uses U.S. export and import data, which easily go back to the 1980s and are much 
more available than state-level data. This feature allows us to exploit state variation in alignment with U.S. strengths. Lastly, the combination of a state-level comparative advantage index with U.S.-level export and import data make the trade exposure measure comparable across states and years.

Higher levels of trade exposure imply that a state has an economy built around goods or services for which the U.S. does not have a comparative advantage. This implies that a state's production takes place in competition with net imports of similar goods or services. On the other hand, lower levels of trade exposure suggest a state has an economy built around an industry in which the U.S. also has a comparative advantage, as suggested by the U.S. being a net exporter of that industry's goods or services.

Since we are primarily interested in assessing whether states' global market integration attenuates the relationship between state voter ideology and state spending, we also include the multiplicative term of the core independent variables to test for any conditional effect.

\section{[INSERT TABLE 1 NEAR HERE]}

\section{Control Variables}

Because the degree of female participation in the work force has been shown to be an important predictor of public spending (Huber and Stephens 2001) we include the percentage of female adults in the labor force. We include a measure of the age of the state population because public spending in the United States is particularly geared towards older adults and children (Busemeyer 2007; Lynch 2006). Using data from the US Census we include the percentage of the state population that is over 65 and under 18 years old. ${ }^{9}$

Gilens (1996) argues that white Americans perceive that African Americans disproportionately benefit from social programs, which depresses support for activist 
government. State-level studies have demonstrated a similar effect, such that states with large black minority populations have lower levels of welfare spending or less generous welfare policies (Brown 1995; Fellowes and Rowe 2004; Soss, et al. 2001; Hero and Preuhs 2007). Accordingly, we include a control for the percentage of the state population that is African American.

Vulnerable groups such as the unemployed have been shown to be supporters of government spending as well as directly increase the costs of social programs (Lowery and Berry 1983; Lewis-Beck and Rice 1985). Therefore, we include the percentage of the unemployed as a control variable.

Following classic accounts such as Wagner (1877; see also Lowery and Berry, 1983), state economic affluence explains government spending, in that high income states have the capacity to spend more. We include state-level real per capita income as well as the growth rate of state-level real per capita income as controls, following earlier work by Burgoon (2001) and Rudra and Haggard (2005). Data on state-level real per capita income and real per capita income growth are collected from the Bureau of Economic Analysis.

The power resources theory suggests that governments controlled by left parties will spend more on state programs (Huber and Stephens 2001; Moller, et al. 2003; Huber, et al. 2006; Kelly and Witko 2012). Party competition encourages political parties to compete with one another for the broadest range of the electorate, motivating them to spend more on social programs (Dawson and Robinson 1963).Therefore, we include state government partisan control and party competition in our model. Partisan control is an index of the party that controls the state senate, house and governorship. It ranges from 0 to 3, with 0 indicating all three branches controlled by the Democratic Party and 3 indicating all three branches controlled by the 
Republican Party. Party competition is a folded Ranney index measuring state-level competition between the two parties (Ranney 1976).

Lastly, considering that the manufacturing industry is the most vulnerable to globalization and that it comprises the largest trade sector, we include \% of manufacturing industry as the total size of the economy as a control (Bernard and Jensen 1995). Since the trade exposure measure has already taken into consideration the size of manufacturing, we exclude this control variable from the trade exposure models. Data on state-level manufacturing are collected from the Bureau of Economic Analysis.

\section{Findings}

Tables 2 and 3 present the results for the pooled cross sectional and time series (CSTS) models for per capita government spending. The overall state public expenditure models are presented in Table 2 and expenditures on welfare are presented in Table 3. We use the two approaches detailed above to consider a state's degree of global market integration. The first approach focuses on the size of the state's exporting economy (trade dependence) whereas the second considers the positioning or comparative global advantage or disadvantage of that state's economy (trade exposure). Due to their empirical and theoretical overlap we test the moderating effects of trade exposure and trade dependence on the opinion-policy connection separately to avoid the inflation of standard errors.

\section{[INSERT TABLE 2 NEAR HERE]}

\section{Total Expenditures}

We begin in Models (1) and (2) by excluding any interaction term from the model to demonstrate that we are working with data that replicate the standard finding in the literature; 
these results show that after controlling for a variety of other structural factors, states with more liberal state populations tend to have higher levels of total public expenditures. This independent connection between state liberalism and state public expenditures is displayed graphically in Figure 1 and is conventionally seen as evidence of opinion-policy congruence. ${ }^{10}$ We repeat this same replication approach in models (1) and (2) of Table 2; in each case, opinion liberalism has an independent effect on state spending, demonstrating that this connection is robust even with alternative dependent variables and changes to the model specification.

\section{[INSERT FIGURE 1 NEAR HERE]}

Next, we turn to Table 2, Model (3), which builds upon the baseline model by adding the interaction term between the trade exposure measure and the opinion liberalism measure. The interaction term reaches conventional thresholds for statistical significance suggesting that trade exposure indeed moderates the relationship between opinion liberalism and the relative degree of overall public expenditures in the American states. The interaction term makes straightforward interpretation of the coefficients challenging from the tables alone. Therefore, we use the Clarify program to graph the relationship between opinion and state spending for low and high trade exposure states, where high and low are defined as plus or minus one standard deviation from the mean exposure (King, et al. 2000).

\section{[INSERT FIGURE 2 NEAR HERE]}

The key hypothesis test assesses whether higher levels of trade exposure attenuates the overall positive opinion-policy connection. Policy convergence theory expects that the ideological desires of citizens will be less important as states become more exposed to global markets. In other words, citizen ideology should have lower correspondence with public 
expenditures in highly exposed states. The room to maneuver hypothesis diverges from this expectations, as it suggests that state governments have the ability to adopt different degrees of state spending to confront the pressures of high global exposure; and because states have various options, the state spending approaches will reflect the ideological orientation of the citizenry. As can be seen from Figure 2, the association between citizen opinion and the states' degree of public spending is not weaker in states with high trade exposure. When states are exposed to low levels of globalization, moving from a low degree to a high degree of liberalism does not significantly alter the degree of overall state spending. However, when states face high trade exposure, moving from a low degree to a high degree of liberalism increases total state per capita spending by about 20\%. The marginal effect of citizen opinion, indicated by the slope of the predicted lines, is higher in states with high trade exposure compared to states with low trade exposure. This finding that opinion and public spending is more congruent in highly exposed states diverges sharply from the expectations of convergence theory and aligns well with the room to maneuver perspective.

Next, we turn to model (4), which adds the interaction term between the trade dependence measure and the opinion liberalism measure. The interaction term reaches a standard threshold $(P<.05)$ for statistical significance indicating that we can have some confidence that trade dependence moderates the relationship between opinion liberalism and the relative degree of overall public expenditures in the American states. To clarify the understanding of the interaction term we again graph a figure that displays the relationship between opinion and state spending; in Figure 3, we plot the predicted overall state government spending based on citizen opinion liberalism for low and high trade dependence states by using the Clarify program (King, et al. 2000). The pattern is familiar. The relationship between opinion 
liberalism and overall state spending, indicated by the slope of the predicted line, is stronger in high trade dependent states compared to low trade dependent states. Because there is no attenuation of opinion's marginal effect on spending in highly dependent states relative to low dependent states, the convergence theory is again unsupported, even when considering this alternative measure of states' integration to the global marketplace. Indeed, the results again suggest that global pressures increase the correspondence between citizen opinion and policy. This suggests that states react to global market pressures in a way consistent with the ideological predispositions of their citizens.

\section{[INSERT FIGURE 3 NEAR HERE]}

\section{Welfare Expenditures}

Because states have great leeway to make targeted and diverse policy innovations to address similar state challenges, it is often difficult to fully standardize states' relative commitment to addressing specific issues by measuring spending on a particular program. This explains why many past studies use total expenditures (Radcliff and Saiz 1998) or a large basket of diverse state policies (Wright, et al. 1987) to measure the degree of state policy liberalism. However, the policy convergence literature has had a special emphasis on welfare state convergence, as social safety net spending is seen as the most inefficient spending (Swank 2005; Adsera and Boix 2002). It may be that when welfare spending is considered, rather than overall state spending, the attenuation effect predicted by the policy convergence theory will emerge; we may see the marginal effect of opinion on spending reduced in high trade environments relative to low trade environments. To test this we run the same sequence of models but change the dependent variable to per capita state spending on welfare. ${ }^{11}$ These results are presented in Table 3. 


\section{[INSERT TABLE 3 NEAR HERE]}

The first welfare spending hypothesis test is shown in Model (3) of Table 3. The interaction term of trade exposure and state opinion liberalism reaches a standard threshold for statistical significance, which suggests that trade exposure conditions the relationship between opinion liberalism and welfare spending. Again, to better understand the results we graphically display the slope of opinion liberalism for low and high level trade exposure states by using the Clarify program (see Figure 4). Consistent with the results from the previous models, Figure 4 shows that the strength of the citizen opinion-welfare spending relationship, as indicated by the slope, is somewhat steeper for high exposure states compared to low exposure states. This again differs from the convergence theory expectation that citizen opinion will become disconnected from policy in states that are highly exposed to global markets. Once more, these results support the expectations of the room to maneuver hypothesis, which predicts no attenuation of the citizen opinion-policy connection when states are highly exposed to global markets.

Finally, we turn to model (4) of Table 3, which again uses welfare expenditures as the dependent variable but uses the trade dependence measure to capture states' global market integration. The interaction term of trade dependence and citizen liberalism is not statistically significant. Figure 5 shows that the independent association of citizen liberalism and welfare expenditures is comparable across states with high and low trade dependence (the association is slightly stronger in high dependence environments). Because the link between citizen opinion liberalism and state welfare spending is very similar at high and low levels of trade dependence, the evidence again conforms to the room to maneuver hypothesis. This is the key finding for testing the hypotheses -the relationship between opinion and spending is not lower in high trade states relative to low trade states. 


\section{Discussion}

Because of the implications for the quality of democracy, a large body of work assesses the linkage between public opinion and public policy. Generally the correspondence between opinion and policy has been robust, but in recent years several studies have sought to identify factors that weaken or strengthen the opinion-policy connection. Burstein has even challenged researchers to more deeply study how various contextual factors promote or attenuate the opinion-policy connection (see Burstein 2010). This paper follows this conditional perspective by connecting well-known economic globalization theories to the opinion-policy congruence literature. Drawing upon competing theories of economic globalization, we leverage the special characteristics of the American states, such as the availability of over-time opinion data, a wide range of citizen ideology, the state economies' large differences in the degree of global market integration, and state governments' substantial control over public spending, to explicitly assess whether global market integration conditions the ties between citizen opinion and certain public policies.

Our results suggest that the degree of global market integration does moderate the relationship between public opinion and state spending. Yet, the specific nature of this moderation casts doubt on the well-known policy convergence thesis. Under conditions of high economic globalization, rather than public opinion becoming less relevant as a determinant of fundamental public spending policies, thereby flattening the opinion-policy linkage as the convergence thesis implies, higher trade seems to often strengthen the positive association between opinion and policy in the American states. This empirical pattern fits with the room to maneuver perspective that suggests states have various options when selecting the suitable solutions to the anxieties and challenges associated with economies that are highly exposed to 
international pressures. In highly globalized state economies, our results suggest that a liberal citizenry will be especially likely to see their state increases public expenditures. But when citizens hold conservative views their argument for a neo-liberal policy path of low public spending is particularly likely to manifest in state policy. Because both the policy convergence and room to maneuver perspectives argue that state spending becomes more salient in a highly globalized context, one way to comprehend these results is to view the findings through the lens of past studies that show that the opinion-policy linkage is strongest when policies are highly salient (e.g. Lax and Phillips 2012).

Despite much of the theorizing about economic globalization deeply conditioning state sovereignty and the associated implications for democratic responsiveness, the cross-national globalization literature has paid "little attention to mass politics" (Hellwig 2007, 772). Part of the explanation for the lack of attention to citizen opinions in this literature probably stems from the scarcity of multi-decade, cross-nationally comparable opinion data. Fortunately, the U.S. states have long been used to consider the opinion-policy linkage. But even with the growth of U.S. global trade over time, and the appreciation that the fiscally decentralized American states should be especially sensitive to global market pressures (Piven 2001; Weingast 1995), to date no empirical studies at the U.S. sub-national level explore the potential effect of global market integration on the connection between opinion and public policies. As such, our paper contributes in multiple ways. It offers one of the only tests of well-known competing views of economic globalization as it relates to the connection between mass attitudes and public policy and it shows that global market integration should be considered a potential (even likely) moderator of the opinion policy linkage in the American states. 
Finally, this paper contributes to the unresolved debate about whether the public opinionpolicy linkage has increased or decreased in the United States over the past several decades (for a review of the debate see Burstein 2003; 2010). If the public opinion-policy linkage indeed has decreased, at first glance then it seems plausible that economic globalization has played a role. The time period considered in this debate corresponds closely with the large relative increase in U.S. global trade, with global trade nearly tripling over the past 30 years (Owen and Quinn 2014). And certainly the most prominent theories of economic globalization explicitly suggest that the power of the public over policy will be directly affected by increasing international market involvement and competition. Our initial results suggest that across the American states, high levels of global market integration correspond with somewhat stronger links between public opinion and public policy. Accordingly, our results suggest that the increase in international market exposure is not a likely culprit of a decline in the public opinion-policy linkage over time in the U.S. Instead, it actually may be a countervailing force against the general tide of opinionpolicy attenuation.

Perhaps more than anything else, our results from a diversity of models can be seen as consistent evidence against the opinion-policy attenuation effect predicted by the policy convergence thesis. Still, because our work represents a preliminary exploration of economic globalization and the opinion-policy linkage in the American states, and because some of our results and robustness checks show no conditioning (neither strengthening nor weakening of the opinion-policy link), our results about the link between opinion and policy in highly globalized states should be viewed with some caution. In particular, poor measurement of the key variables, particularly the globalization measures, could be the source of the null or significant conditional results. Noisy measures inflate standard errors and often lead to null results; biased measures, 
and other data and modeling imperfections, could produce false positive findings. Critically then, more work, with different modeling approaches, data, and assumptions are needed to better understand why the connection between opinion and policy appears to be equal or somewhat stronger in highly globalized states. Given the overall paucity of research in this specific area, we hope our work encourages new research exploring global market exposure and the opinionpolicy linkage in the American states. 
Table 1: Descriptive Statistics for Core Variables. (U.S. States, 1987-2006)

\begin{tabular}{lll}
\hline VARIABLES & Mean & St. Dev. \\
\hline Total State Expenditures (per capita) & $3,558.3$ & $1,513.8$ \\
State Welfare Expenditures (per capita) & 721.4 & 369.5 \\
Liberalism & 20.5 & 3.3 \\
Trade Exposure & 7.5 & 2.4 \\
Trade Dependence* & 5.6 & 3.3 \\
Liberalism x Trade Exposure & 155.0 & 55.6 \\
Liberalism x Trade Dependence* & 116.8 & 77.7 \\
\% Unemployment & 5.3 & 1.4 \\
\% Black & 10.1 & 9.4 \\
Real Per Capita Income (thousands) & 32.3 & 4.0 \\
\% Real Per Capita Income Growth & 1.4 & 2.0 \\
Dependency Ratio & 0.62 & 0.05 \\
\% Female Labor Force Partic. Rate & 60.0 & 4.5 \\
Partisan Control & 1.4 & 1.0 \\
Party Competition & .63 & .1 \\
\% Manufacturing Output & 15.0 & 6.3 \\
Observations & 966 & \\
Number of states & 50 & \\
\hline One sat Is & &
\end{tabular}

*One state is missing for the trade dependence data. All other statistics are from all 50 states. 
Table 2: Total State Expenditures in U.S. States, 1987-2006

\begin{tabular}{|c|c|c|c|c|}
\hline \multirow[b]{2}{*}{ VARIABLES } & \multicolumn{4}{|c|}{ Per Capita Total State Expenditures } \\
\hline & $(1)$ & $(2)$ & $(3)$ & (4) \\
\hline Liberalism & $\begin{array}{l}21.82^{* * *} \\
(6.34)\end{array}$ & $\begin{array}{l}17.41 * * * \\
(6.39)\end{array}$ & $\begin{array}{l}-48.73 * * * \\
(13.04)\end{array}$ & $\begin{array}{l}-5.74 \\
(8.91)\end{array}$ \\
\hline Trade Exposure & $\begin{array}{l}-20.45^{*} \\
(11.14)\end{array}$ & & $\begin{array}{l}-174.72 * * * \\
(29.21)\end{array}$ & \\
\hline Trade Dependence & & $\begin{array}{l}-7.73 \\
(10.17)\end{array}$ & & $\begin{array}{l}-98.28^{* * *} \\
(37.25)\end{array}$ \\
\hline Liberalism x Trade Exposure & & & $\begin{array}{l}8.71^{* * *} \\
(1.54)\end{array}$ & \\
\hline Liberalism x Trade Dependence & & & & $\begin{array}{l}4.04 * * \\
(1.59)\end{array}$ \\
\hline \% Unemployment & $\begin{array}{l}26.67^{* *} \\
(11.05)\end{array}$ & $\begin{array}{l}18.48^{*} \\
(10.92)\end{array}$ & $\begin{array}{l}37.95^{* * *} \\
(11.62)\end{array}$ & $\begin{array}{l}20.05^{*} \\
(10.95)\end{array}$ \\
\hline$\%$ Black & $\begin{array}{l}26.38 \\
(30.03)\end{array}$ & $\begin{array}{l}17.98 \\
(29.11)\end{array}$ & $\begin{array}{l}32.37 \\
(30.09)\end{array}$ & $\begin{array}{l}6.55 \\
(29.65)\end{array}$ \\
\hline Real Per Capita GDP Growth & $\begin{array}{l}29.02^{* *} \\
(13.96)\end{array}$ & $\begin{array}{l}21.88 \\
(14.63)\end{array}$ & $\begin{array}{l}30.62 * * \\
(13.83)\end{array}$ & $\begin{array}{l}21.63 \\
(14.52)\end{array}$ \\
\hline Real Per Capita Income & $\begin{array}{l}1.11 \\
(8.91)\end{array}$ & $\begin{array}{l}-0.06 \\
(9.04)\end{array}$ & $\begin{array}{l}5.14 \\
(8.91)\end{array}$ & $\begin{array}{l}0.53 \\
(9.08)\end{array}$ \\
\hline Dependency Ratio & $\begin{array}{l}-1,703.81^{* * *} \\
(455.12)\end{array}$ & $\begin{array}{l}-757.17^{*} \\
(425.09)\end{array}$ & $\begin{array}{l}-2,231.48^{* * *} \\
(446.80)\end{array}$ & $\begin{array}{l}-625.69 \\
(420.60)\end{array}$ \\
\hline Female Labor Force Partic. Rate & $\begin{array}{l}12.85^{*} \\
(7.02)\end{array}$ & $\begin{array}{l}5.36 \\
(6.71)\end{array}$ & $\begin{array}{l}11.01 \\
(7.04)\end{array}$ & $\begin{array}{l}6.16 \\
(6.59)\end{array}$ \\
\hline Partisan Control & $\begin{array}{l}-22.84 * \\
(13.60)\end{array}$ & $\begin{array}{l}-25.71^{*} \\
(13.56)\end{array}$ & $\begin{array}{l}-13.43 \\
(13.58)\end{array}$ & $\begin{array}{l}-16.98 \\
(13.38)\end{array}$ \\
\hline Party Competition & $\begin{array}{l}481.86^{* * *} \\
(186.01)\end{array}$ & $\begin{array}{l}532.50 * * * \\
(185.70)\end{array}$ & $\begin{array}{l}329.60 * \\
(188.42)\end{array}$ & $\begin{array}{l}466.25^{* *} \\
(182.85)\end{array}$ \\
\hline \% Manufacturing Output & & $\begin{array}{l}-10.63^{*} \\
(9.36)\end{array}$ & & $\begin{array}{l}-11.46^{*} \\
(8.92)\end{array}$ \\
\hline Year Fixed Effects & (included) & (included) & (included) & (included) \\
\hline State Fixed Effects & (included) & (included) & (included) & (included) \\
\hline Constant & $\begin{array}{l}559.17 \\
(654.84)\end{array}$ & $\begin{array}{l}812.29 \\
(623.39)\end{array}$ & $\begin{array}{l}2,116.69^{* * *} \\
(673.45)\end{array}$ & $\begin{array}{l}1,349.08^{* *} \\
(638.59)\end{array}$ \\
\hline Observations & 966 & 946 & 966 & 946 \\
\hline R-squared & 0.97 & 0.97 & 0.97 & 0.97 \\
\hline Number of state & 49 & 48 & 49 & 48 \\
\hline
\end{tabular}

Robust standard errors in parentheses

${ }^{* * *} \mathrm{p}<0.01,{ }^{* *} \mathrm{p}<0.05,{ }^{*} \mathrm{p}<0.1$ 
Table 3: State Welfare Expenditures in U.S. States, 1987-2006

\begin{tabular}{|c|c|c|c|c|}
\hline \multirow[b]{2}{*}{ VARIABLES } & \multicolumn{4}{|c|}{ State Welfare Spending (per capita) } \\
\hline & $(1)$ & $(2)$ & $(3)$ & $(4)$ \\
\hline Liberalism & $\begin{array}{l}7.67 * * * \\
(2.54)\end{array}$ & $\begin{array}{l}6.13^{* *} \\
(2.58)\end{array}$ & $\begin{array}{l}-10.15^{* *} \\
(4.82)\end{array}$ & $\begin{array}{l}2.41 \\
(3.90)\end{array}$ \\
\hline Trade Exposure & $\begin{array}{l}-9.50^{*} \\
(4.86)\end{array}$ & & $\begin{array}{l}-48.45^{* * *} \\
(12.32)\end{array}$ & \\
\hline Trade Dependence & & $\begin{array}{l}10.33^{* * *} \\
(3.20)\end{array}$ & & $\begin{array}{l}-4.20 \\
(13.94)\end{array}$ \\
\hline Liberalism $x$ Trade Exposure & & & $\begin{array}{l}2.20^{* * *} \\
(0.61)\end{array}$ & \\
\hline Liberalism $x$ Trade Dependence & & & & $\begin{array}{l}0.65 \\
(0.59)\end{array}$ \\
\hline \% Unemployment & $\begin{array}{l}18.49^{* * *} \\
(4.32)\end{array}$ & $\begin{array}{l}11.68^{* * *} \\
(4.35)\end{array}$ & $\begin{array}{l}21.34^{* * *} \\
(4.38)\end{array}$ & $\begin{array}{l}11.93^{* * *} \\
(4.32)\end{array}$ \\
\hline \% Black & $\begin{array}{l}18.30^{*} \\
(10.66)\end{array}$ & $\begin{array}{l}25.60^{* *} \\
(10.75)\end{array}$ & $\begin{array}{l}19.81^{*} \\
(10.57)\end{array}$ & $\begin{array}{l}23.76^{* *} \\
(10.83)\end{array}$ \\
\hline Real Per Capita GDP Growth & $\begin{array}{l}-4.10 \\
(4.28)\end{array}$ & $\begin{array}{l}-6.55 \\
(4.36)\end{array}$ & $\begin{array}{l}-3.69 \\
(4.30)\end{array}$ & $\begin{array}{l}-6.59 \\
(4.35)\end{array}$ \\
\hline Real Per Capita Income & $\begin{array}{l}3.61 \\
(2.48)\end{array}$ & $\begin{array}{l}3.70 \\
(2.50)\end{array}$ & $\begin{array}{l}4.63^{*} \\
(2.52)\end{array}$ & $\begin{array}{l}3.79 \\
(2.50)\end{array}$ \\
\hline Dependency Ratio & $\begin{array}{l}-539.07 * * * \\
(181.55)\end{array}$ & $\begin{array}{l}-337.30 * \\
(174.28)\end{array}$ & $\begin{array}{l}-672.32 * * * \\
(182.64)\end{array}$ & $\begin{array}{l}-316.20 * \\
(173.70)\end{array}$ \\
\hline Female Labor Force Partic. Rate & $\begin{array}{l}10.30^{* * *} \\
(2.72)\end{array}$ & $\begin{array}{l}8.14^{* * *} \\
(2.53)\end{array}$ & $\begin{array}{l}9.83^{* * *} \\
(2.72)\end{array}$ & $\begin{array}{l}8.27^{* * * *} \\
(2.53)\end{array}$ \\
\hline Partisan Control & $\begin{array}{l}-3.04 \\
(5.08)\end{array}$ & $\begin{array}{l}-5.61 \\
(5.13)\end{array}$ & $\begin{array}{l}-0.67 \\
(5.13)\end{array}$ & $\begin{array}{l}-4.20 \\
(5.19)\end{array}$ \\
\hline Party Competition & $\begin{array}{l}-99.75 \\
(65.70)\end{array}$ & $\begin{array}{l}-51.70 \\
(64.55)\end{array}$ & $\begin{array}{l}-138.19^{* *} \\
(64.70)\end{array}$ & $\begin{array}{l}-62.34 \\
(65.59)\end{array}$ \\
\hline \% Manufacturing Output & & $\begin{array}{l}-9.22 * * * \\
(2.02)\end{array}$ & & $\begin{array}{l}-9.35 * * * \\
(2.03)\end{array}$ \\
\hline Year Fixed Effects & (included) & (included) & (included) & (included) \\
\hline State Fixed Effects & (included) & (included) & (included) & (included) \\
\hline Constant & $\begin{array}{l}-133.12 \\
(264.31)\end{array}$ & $\begin{array}{l}-68.44 \\
(261.28)\end{array}$ & $\begin{array}{l}260.19 \\
(275.34)\end{array}$ & $\begin{array}{l}17.70 \\
(271.75)\end{array}$ \\
\hline Observations & 966 & 946 & 966 & 946 \\
\hline R-squared & 0.93 & 0.93 & 0.93 & 0.93 \\
\hline Number of state & 49 & 48 & 49 & 48 \\
\hline
\end{tabular}

Robust standard errors in parentheses

*** $\mathrm{p}<0.01,{ }^{* *} \mathrm{p}<0.05,{ }^{*} \mathrm{p}<0.1$ 
Figure 1: Predicted Total State Expenditures as Liberalism Varies

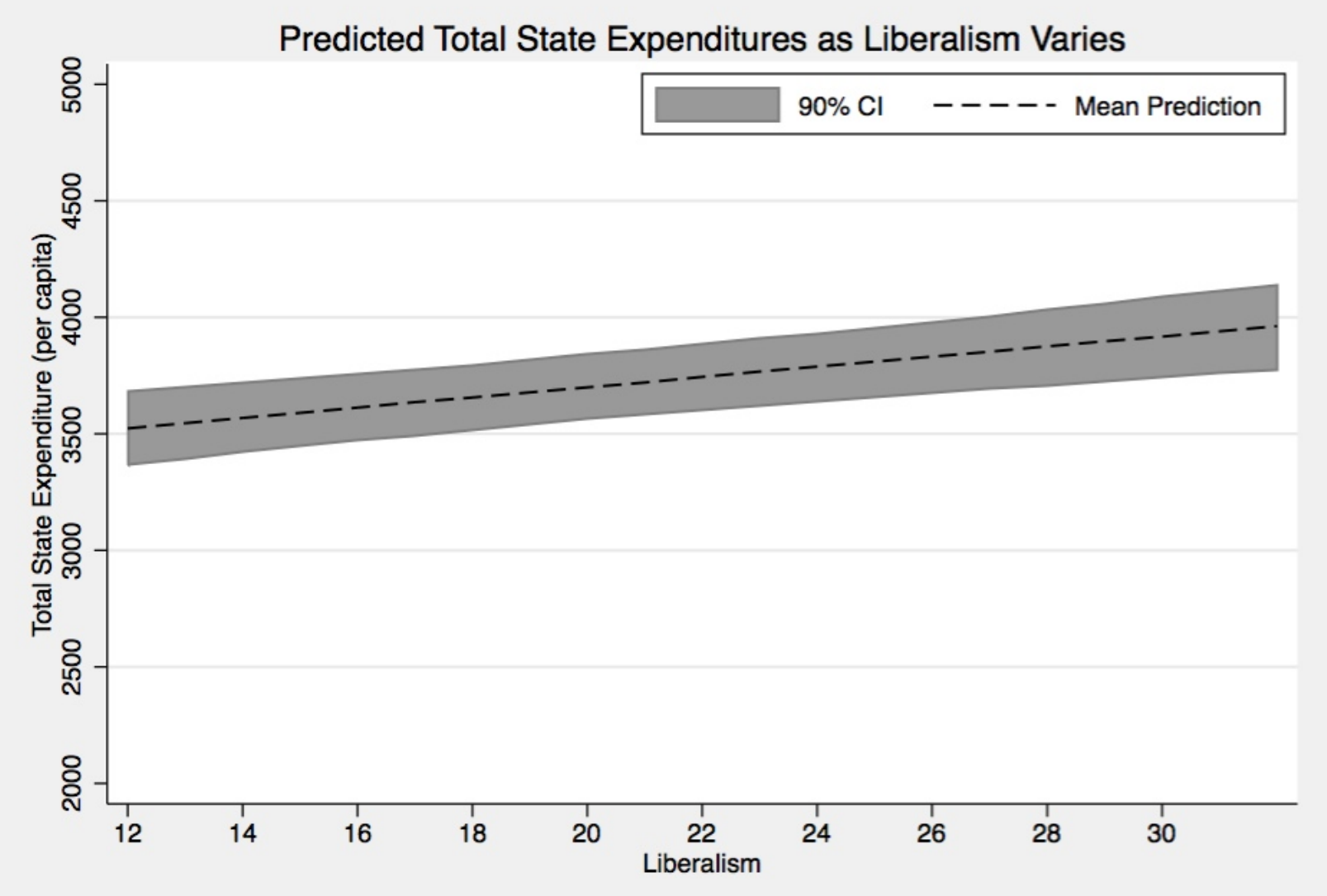


Figure 2: Total State Expenditures, Liberalism, and Trade Exposure

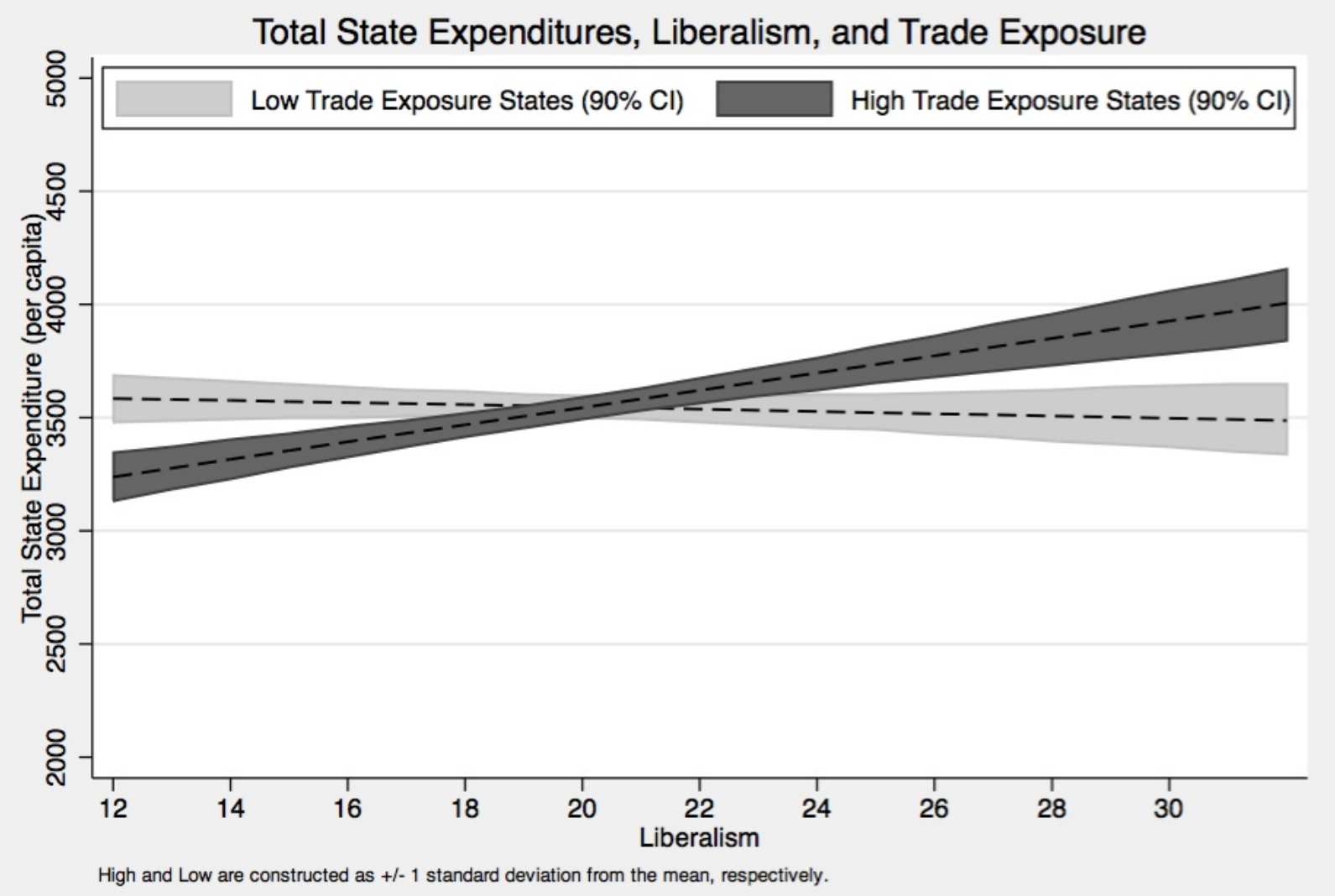


Figure 3: Total State Expenditures, Liberalism, and Trade Dependence

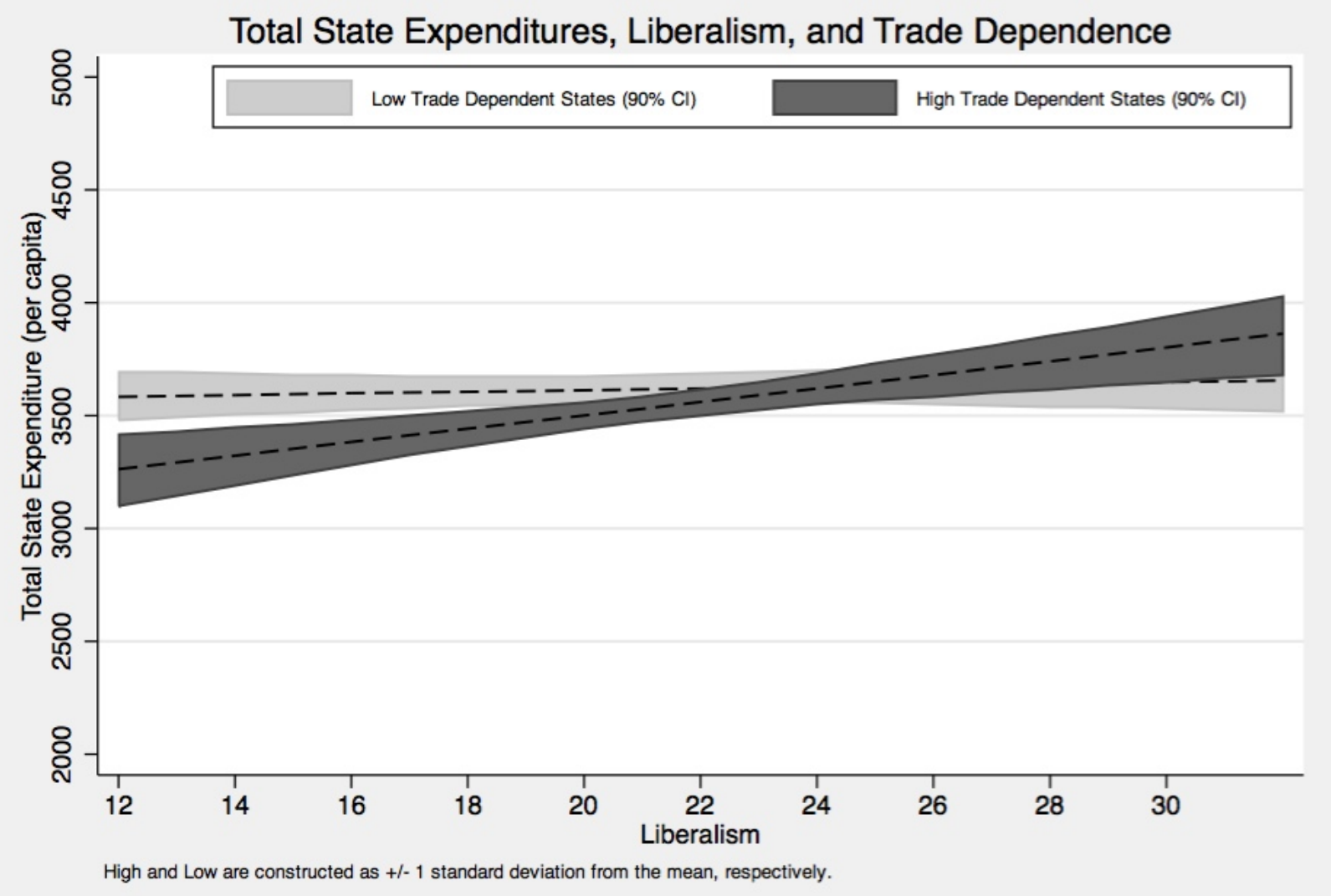


Figure 4: State Welfare Expenditures, Liberalism, and Trade Exposure

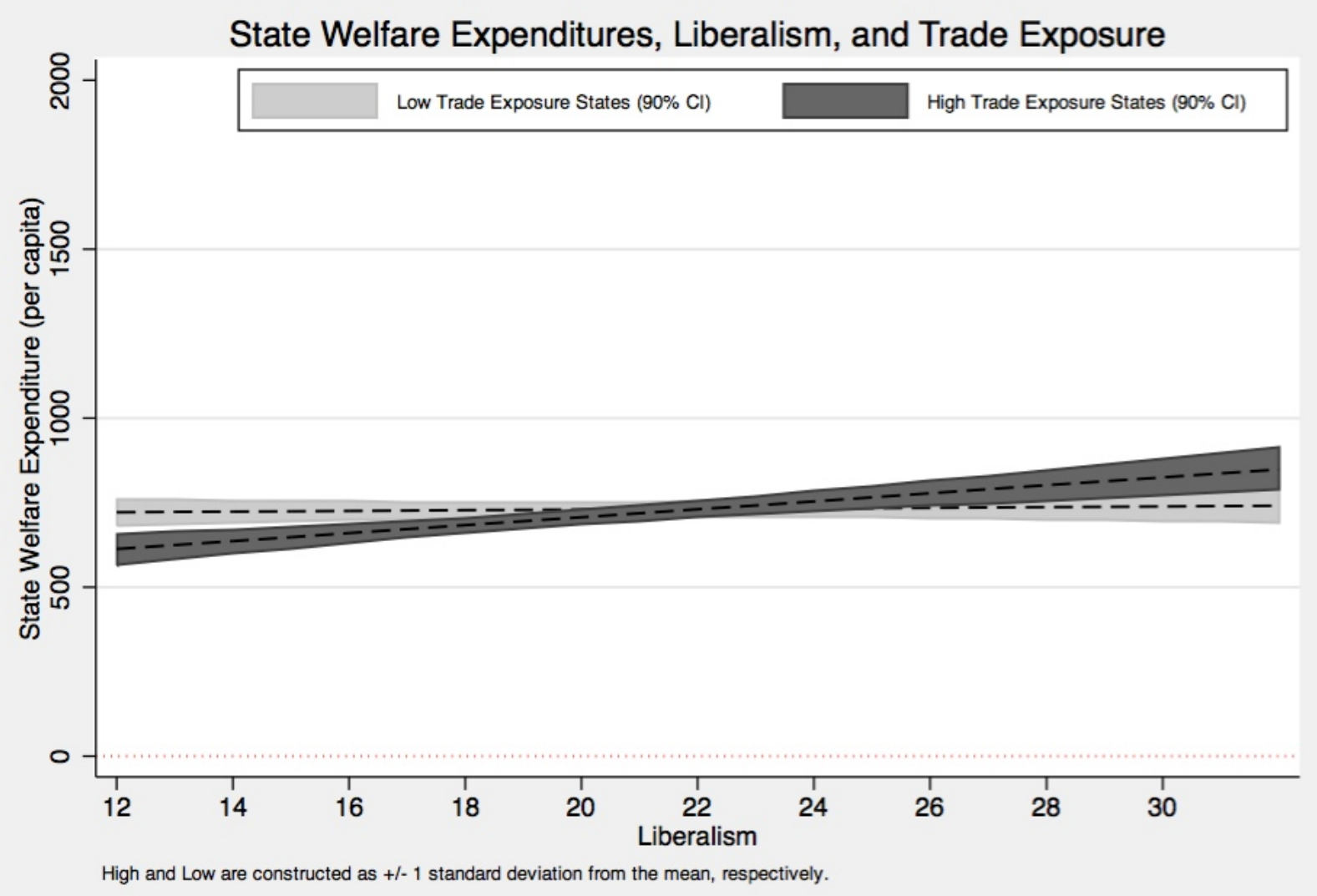


Figure 5: State Welfare Expenditures, Liberalism, and Trade Dependence

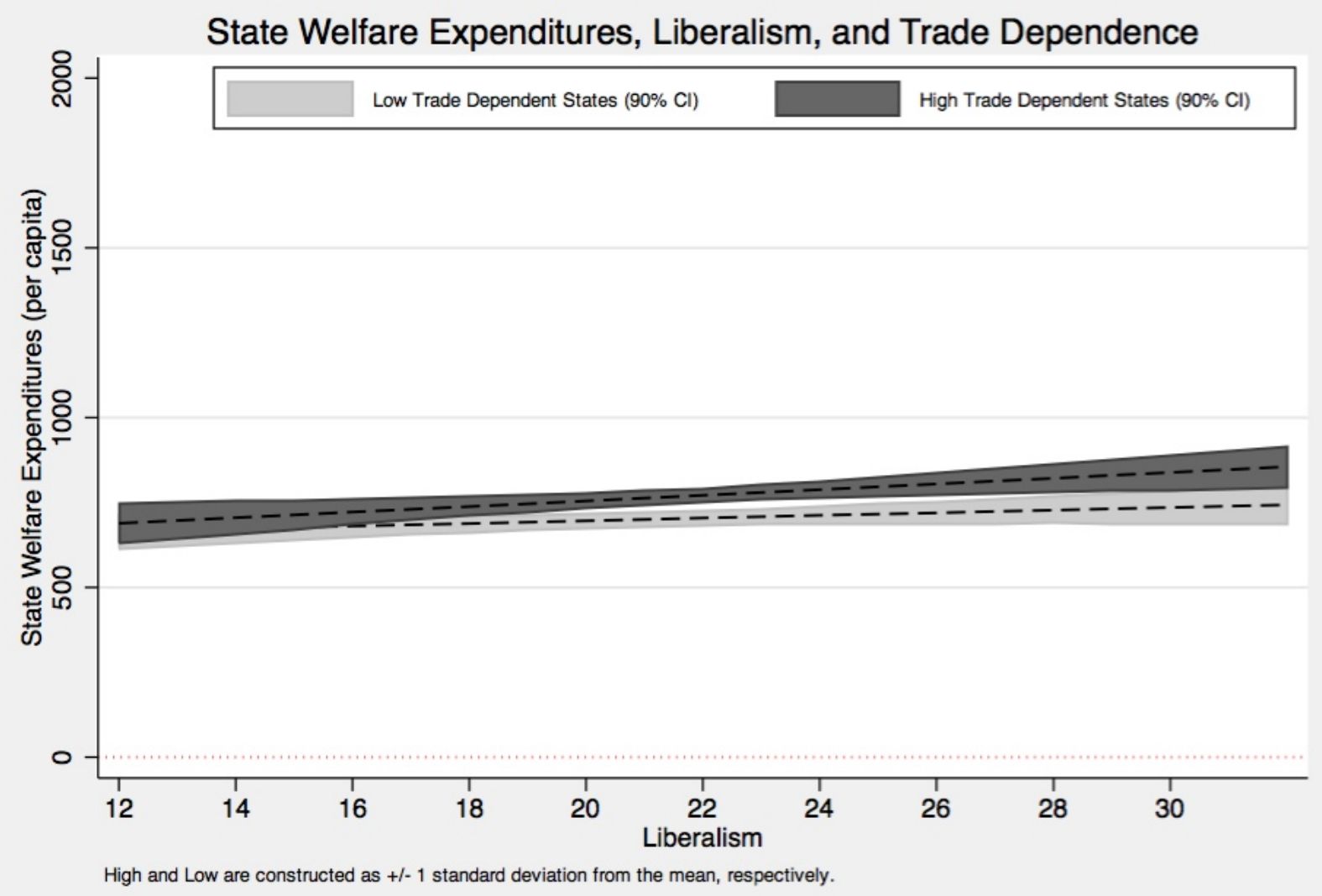




\section{Appendix 1: Construction of Trade Exposure Index}

In this section we outline the construction of trade exposure, which differs from trade dependence in that it is a measure of global market positioning rather than the relative size of a state's international trading economy. We consider two components for the measure: (1) a state's comparative advantage in the production of a particular good or service, and (2) where those particular industries fall along the net export - net import spectrum for the U.S. as a whole. We discuss each in turn.

Balassa (1965) laid the foundation for measuring revealed comparative advantage (RCA) index. For country A and any good $i$, the standard Balassa RCA index is simply good $i$ 's share of total exports in country A relative to good $i$ 's share of world exports. For example, if $i$ exports coming from country A were 30\% of all of country A's exports but $i$ exports from the world were only $15 \%$ of total world exports, then country A has an RCA index of 2 in the production of good $i$. And because it is greater than one, country A is said to have a revealed comparative advantage in good $i$. One limiting characteristic of the RCA index is that it is limited to a particular good, service, or industry. To resolve this issue, we consider three industries (i.e. services, agriculture, and manufacturing) instead of trade in a single industry. A second constraint is that disaggregated U.S. state-level international export data by industries is limited, especially in the years before 2000. Therefore we use employment in a given industry in lieu of exports to compose an adjusted Balassa RCA index and use it as the first component of our index. We construct the following adjusted RCA measure for each state $s$, at time $t$, and where US is the aggregate United States data, and Emp is employment:

$$
\text { adj. RCA }=\left(\frac{E m p_{s i t} / E m p_{s t}}{E m p_{U S t i t} / E m p_{U S t}}\right)
$$


The second component of our index is the nature of the industry or the goods and services being traded. Our goal here is to identify how the goods and services that states export abroad map onto the United State's net export - net import continuum. Do states specialize in goods that compete with foreign imports or do they specialize in industries that the US itself has a revealed comparative advantage in? For this component we construct an adjusted Grubel-Lloyd (GL) index of intra-industry trade as shown below (Grubel and Lloyd 1971; 1975). Different from the original GL index that uses absolute value of net exports, we use the real value of net exports since we are interested in mapping industries into the entire net export - net import spectrum. Our adjusted GL index ranges from -1 to 1 , with 1 meaning there are only exports and no imports of industry $i$-related goods or services in the U.S., and -1 meaning there are only imports and no exports of industry $i$-related goods in the U.S..

$$
\text { adj. GL }=\left(\frac{\left(X_{U S S t}-M_{U S S t}\right)}{\left(X_{U S S i t}+M_{U S S t}\right)}\right)
$$

By combining the two components, we create a measure of trade exposure, which is an index of states' comparative advantage in particular industries weighted by an industry's position on the U.S. net exports - net import spectrum. Multiplying the two components together allows comparison across states and years.

$$
\text { Trade Exposure } \mathrm{it}=\sum_{i}^{I}\left(\frac{E m p_{s i t} / E m p_{s t}}{E m p_{\text {USiti }} / E m p_{\text {USE }}}\right) \times\left(\frac{\left(X_{\text {USSt }}-M_{\text {USSit }}\right)}{\left(X_{\text {USSt }}+M_{\text {USSt }}\right)}\right)(-1)
$$

The first component in parenthesis is the adjusted RCA index and the second is the adjusted GL index. We also take the negative so that higher levels of trade exposure imply that a state has a comparative advantage in goods or services for which the U.S. does not have a comparative advantage in. This implies that a state's production takes place alongside U.S. net 
imports of similar goods or services. On the other end, lower levels of trade exposure suggest a state has a comparative advantage in an industry in which the U.S. also has a comparative advantage in as suggested by the U.S. being a net exporter of that industry's goods or services.

The employment data for the American states come from the U.S. Bureau of Economic Analysis' Regional Economic Accounts, while the U.S. export data come from the World Trade Organization's Statistics Database. Industry-level data spans the SIC and NAICS era classification systems. In order to make the two systems speak to each other, we converted the SIC data to 2-digit NAICS when possible, and also used only finance, insurance, and real estate as a proxy for services. In its raw form, trade exposure centers on zero. For our data, the mean is -.08 , the minimum is -.8 , the maximum is .5 , and has a standard deviation of .21 . For more intuitive presentation in the figures of the main text, we rescaled the measure to be from $0-13$, and with a mean of 7.5 and a standard deviation of 2.5. 


\section{Appendix 2: Robustness to Alternative Specification Using an Error Correction Model}

Banerjee, Dolado, Galbraith and Hendry (1993) recommend the error correction model (ECM) for non-stationary and co-integrated time series data. Following their advice, we conduct various tests on stationarity and cointegration of our panel data. The panel unit root analyses of our dependent variables show that our dependent variables (i.e., total spending and welfare spending) are both non-stationary, and the Westerlund tests detect cointegration between the core independent variables and both dependent variables (Dickey and Fuller 1979; Phillips and Perron 1988; Westerlund 2007; Persyn and Westerlund 2008). Thus, we deem the error correction model as another possible appropriate modeling strategy for our CSTS data. In an ECM, the first-difference of the dependent variable is estimated as an equation of the lagged dependent variable, the first difference and the lagged independent variables, which we specify as:

$$
\Delta Y_{i t}=a+\beta_{1} Y_{i, t-1}+\beta_{2} \Delta X_{i t}+\beta_{3} X_{i, t-1}+e_{i t}
$$

where $\Delta$ represents the annual change, $Y$ is total state expenditures per capita or state welfare expenditures per capita for state $i$ in year $t, X$ is a vector of independent variables, and $e$ is the error term. The results of our error correction models are presented in the table below, and we also use Clarify coupled with Stata 12.0 to draw the following figures to graphically demonstrate the interactive effects of globalization (i.e., trade exposure and trade dependence) and citizen liberalism on spending (King, et al. 2000). While facing higher levels of economic globalization, the association between liberalism and spending, as indicated by the slope of the predicted lines, either stays the same or increases slightly. The bottom line is that even when we use a more stringent modeling strategy, we still find that the congruence of opinion and policy does not attenuate when states face a more globalized environment. 
Table A1: State Government Total and Welfare Spending in Error Correction Models

\begin{tabular}{|c|c|c|c|c|c|c|c|c|}
\hline & \multicolumn{4}{|c|}{ Total Spending } & \multicolumn{4}{|c|}{ Welfare Spending } \\
\hline & \multicolumn{2}{|c|}{ Model (1) } & \multicolumn{2}{|c|}{ Model (2) } & \multicolumn{2}{|c|}{ Model (3) } & \multicolumn{2}{|c|}{ Model (4) } \\
\hline & Coeff. & (SE) & Coeff. & (SE) & Coeff. & (SE) & Coeff. & (SE) \\
\hline Dependent Variable $_{\mathrm{t}-1}$ & .014 & $(.03)$ & .017 & $(.02)$ & -.00 & $(.02)$ & .013 & $(.02)$ \\
\hline$\Delta$ Liberalism & -2.23 & $(6.17)$ & -2.56 & $(6.57)$ & -.24 & (2.39) & .16 & $(2.57)$ \\
\hline Liberalism $_{\mathrm{t}-1}$ & 10.26 & $(8.48)$ & 2.86 & $(4.43)$ & .92 & $(3.42)$ & .03 & $(2.16)$ \\
\hline$\Delta$ Trade Exposure & 2.22 & $(17.38)$ & & & $8.99+$ & (5.29) & & \\
\hline Trade Exposure ${ }_{t-1}$ & 11.75 & (19.33) & & & -1.17 & (8.08) & & \\
\hline$\Delta$ Liberalism $\times \Delta$ Trade Exposure & -6.87 & $(5.14)$ & & & -2.21 & (2.36) & & \\
\hline Liberalism $_{\mathrm{t}-1} \times$ Trade Exposure $_{\mathrm{t}-1}$ & -.24 & $(1.00)$ & & & .25 & $(.41)$ & & \\
\hline$\Delta$ Trade Dependence & & & 3.39 & $(11.65)$ & & & 2.76 & $(3.39)$ \\
\hline Trade Dependence ${ }_{t-1}$ & & & -19.93 & $(16.62)$ & & & $-10.11+$ & (5.93) \\
\hline$\Delta$ Liberalism $\times \Delta$ Trade Dependence & & & -1.11 & (5.38) & & & .67 & $(1.70)$ \\
\hline Liberalism $_{\mathrm{t}-1} \times$ Trade Dependence $_{\mathrm{t}-1}$ & & & .97 & $(.71)$ & & & $.42+$ & $(.25)$ \\
\hline$\Delta \%$ Unemployment & 22.05 & $(16.06)$ & 21.53 & $(17.21)$ & $13.78 *$ & $(5.51)$ & $13.92 *$ & $(5.74)$ \\
\hline \%Unemployment ${ }_{\mathrm{t}-1}$ & -18.17 & $(12.19)$ & -20.53 & (14.58) & 4.43 & (3.43) & 4.05 & $(4.13)$ \\
\hline$\Delta \%$ black & -.46 & $(68.55)$ & -6.29 & (71.62) & 17.17 & $(20.79)$ & 16.02 & $(21.80)$ \\
\hline$\%$ black $_{\mathrm{t}-1}$ & .32 & $(1.14)$ & .78 & $(1.02)$ & -.06 & $(.30)$ & .15 & $(.30)$ \\
\hline$\Delta$ Real per capita income & -23.87 & $(92.61)$ & -19.12 & $(91.80)$ & $62.11^{*}$ & (31.08) & 47.83 & (32.18) \\
\hline Real per capita income $_{t-1}$ & .20 & (3.25) & 1.11 & (3.58) & -.85 & $(1.32)$ & -.08 & $(1.50)$ \\
\hline$\Delta$ Per capita growth & 12.01 & $(28.92)$ & 9.23 & $(28.44)$ & $-21.84 *$ & $(10.03)$ & $-17.63+$ & $(10.29)$ \\
\hline Per capita growth ${ }_{\mathrm{t}-1}$ & 16.85 & (31.98) & 13.41 & (31.09) & $-25.23 *$ & $(10.68)$ & $-20.234+$ & $(10.95)$ \\
\hline$\Delta$ Dependency Ratio & 277.17 & $(869.66)$ & 288.17 & (965.97) & -3.44 & $(280.31)$ & -202.68 & (329.39) \\
\hline Dependency Ratio ${ }_{t-1}$ & 147.33 & $(150.67)$ & 32.98 & $(192.17)$ & 76.86 & $(54.88)$ & 34.21 & (62.39) \\
\hline$\Delta$ Female labor force participation & $-13.52+$ & $(7.05)$ & $-15.08^{*}$ & $(7.64)$ & $-4.46^{*}$ & $(2.15)$ & $-5.37 *$ & $(2.24)$ \\
\hline Female labor force participation ${ }_{t-1}$ & -1.90 & $(3.53)$ & -3.16 & $(4.03)$ & .52 & $(.74)$ & .33 & $(.84)$ \\
\hline$\Delta$ State Government Partisan Control & -10.74 & $(13.90)$ & -11.39 & (13.83) & -5.41 & $(5.54)$ & -4.84 & $(5.80)$ \\
\hline State Government Partisan Control $\mathrm{t}-1$ & -8.42 & $(9.19)$ & -4.57 & $(9.19)$ & -4.67 & $(3.05)$ & -2.95 & $(3.11)$ \\
\hline$\Delta$ Party Competition & 136.01 & $(286.72)$ & 179.33 & $(288.57)$ & 46.99 & (93.39) & 50.73 & $(95.25)$ \\
\hline Party Competition $_{\mathrm{t}-1}$ & 16.76 & $(67.52)$ & 40.54 & $(68.81)$ & 19.66 & $(37.24)$ & 22.53 & $(39.21)$ \\
\hline$\Delta \%$ Manufacturing & & & 2.11 & $(7.16)$ & & & .40 & $(3.08)$ \\
\hline \%Manufacturing ${ }_{\mathrm{t}-1}$ & & & .36 & $(1.43)$ & & & .11 & $(.47)$ \\
\hline Constant & -24.70 & (364.06) & 269.33 & (431.10) & -69.04 & (117.30) & 1.74 & (91.79) \\
\hline $\mathrm{N}$ & 917 & & 898 & & 934 & & 898 & \\
\hline R-Square & .0698 & & .0647 & & .1042 & & .0973 & \\
\hline Wald Chi-Square & 62.35 & & 55.48 & & 50.39 & & 44.01 & \\
\hline
\end{tabular}

Significance levels: + 0.10 level, *0.05 level, ** 0.01 level, *** 0.001 level 
Figure A1: Predicted value of change in total spending as liberalism varies from minimum to maximum values under high and low levels of trade exposure or trade dependence.
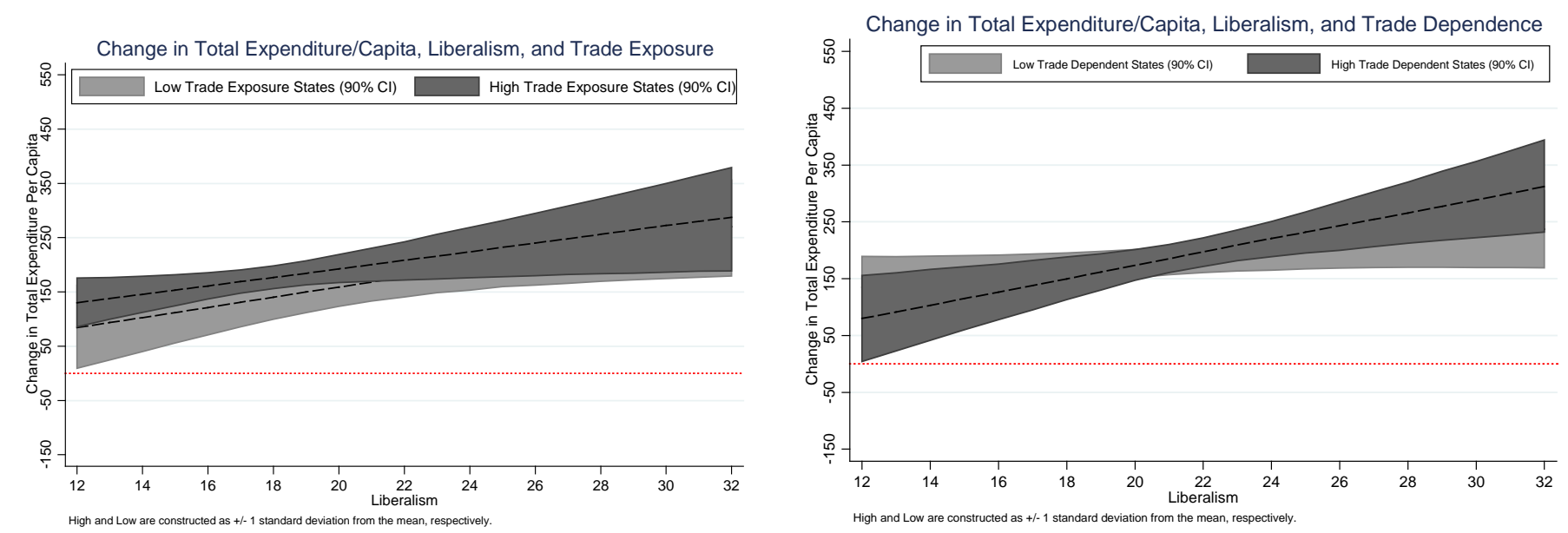

Figure A2: Predicted value of change in welfare spending as liberalism varies from minimum to maximum values under high and low levels of trade vulnerability or exposure.
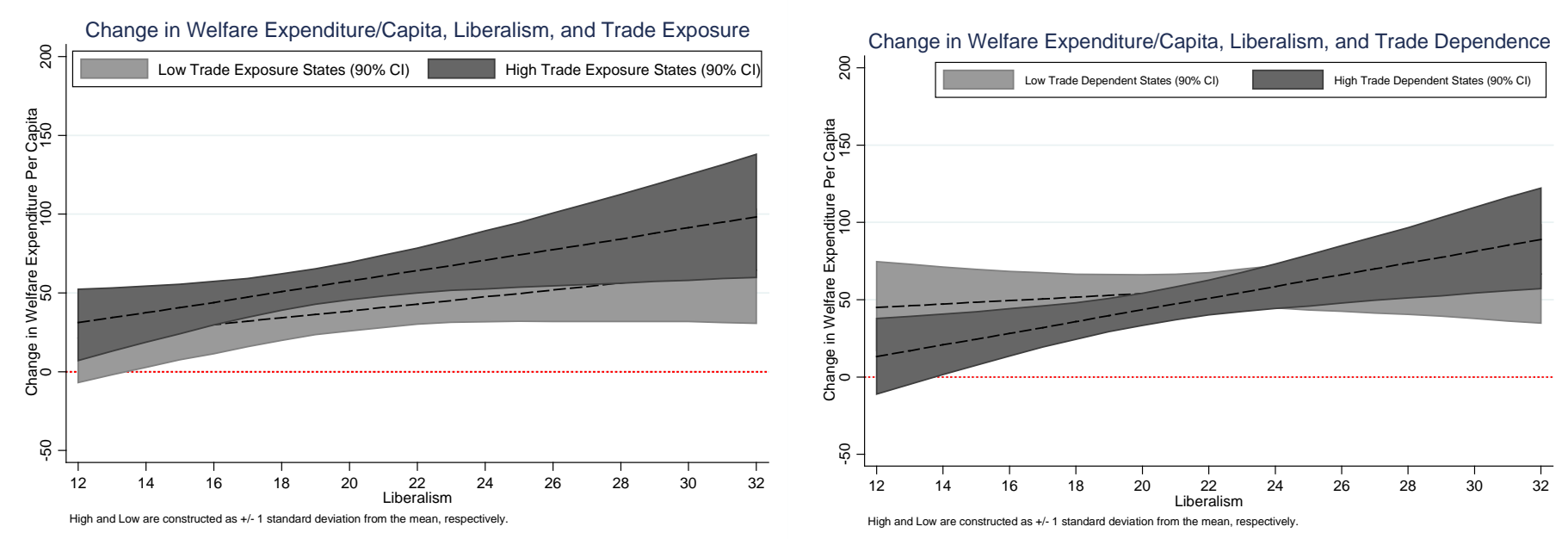


\section{References}

Adsera, Alicia, and Carles Boix. "Trade, Democracy, and the Size of the Public Sector: The Political Underpinnings of Openness.". International Organization 56 (2) (2002): 229-62.

Agné, Hans. "The Autonomy of Globalizing States: Bridging the Gap between Democratic Theory and International Political Economy." International Political Science Review 32 (1) (2011): 43-60.

Albritton, Robert B. "Social Services: Welfare and Health." In Politics in the American States, edited by Virginia Gray, Herbert Jacob and Robert Albritton. Glenview, IL: Scott, Foresman/Little Brown, 1990.

Balassa, Bela. "Trade Liberalisation and "Revealed” Comparative Advantage." The Manchester School 33 (2) (1965): 99-123.

Baltagi, Badi H., Georges Bresson, and Alain Pirotte. "Fixed Effects, Random Effects or Hausman-Taylor?: A Pretest Estimator." Economics Letters 79 (3) (2003): 361-69.

Banerjee, Anindya, Juan Dolado, John W. Galbraith, and David F. Hendry. Co-Integration, Error-Correction, and the Econometric Analysis of Non-Stationary Data. New York: Oxford University Press, 1993.

Bartels, Larry. Unequal Democracy: The Political Economy of the New Gilded Age. New Jersey: Princeton University Press, 2008.

Bernard, Andrew, and J. Bradford Jensen. " Exporters, Jobs, and Wages in U.S. Manufacturing: 1976-1987." Brookings Papers on Economic Activity: Microeconomics, Washington, D.C.: Brookings Institution. (1995): 67-119. 
Berry, William D. , Evan J. Ringquist, Richard C. Fording, and Russell L. Hanson. "Measuring Citizen and Government Ideology in the American States, 1960-93." American Journal of Political Science 42 (1) (1998): 327-48.

Brace, Paul, Kellie Sims-Butler, Kevin Arceneaux, and Martin Johnson. "Public Opinion in the American States: New Perspectives Using National Survey Data." American Journal of Political Science 46 (1) (2002): 173-89.

Brooks, Clem, and Jeff Manza. "Why Do Welfare States Persist?". Journal of Politics 68 (4) (2006a): 816-27.

Brooks, Clem, and Jeff Manza. "Social Policy Responsiveness in Developed Democracies." American Sociological Review 71(3) (2006b): 474-94.

Brown, Robert D. "Party Cleavages and Welfare Effort in the American States." The American Political Science Review 89 (1) (1995): 23-33.

Burgoon, Brian. "Globalization and Welfare Compensation: Disentangling the Ties That Bind." [In English]. International Organization 55 (3) (2001): 509-51.

Burstein, Paul. "The Impact of Public Opinion on Public Policy: A Review and an Agenda." Political Research Quarterly 56 (1) (2003): 29-40.

—. "Public Opinion, Public Policy, and Democracy." In Handbook of Politics: State and Society in Global Perspective, edited by Kevin T. Leicht and J. Craig Jenkins: Springer Science+Business Media, LLC, 2010.

Busemeyer, Marius R. "Determinants of Public Education Spending in 21 Oecd Democracies, 1980-2001." Journal of European Public Policy 14 (4) (2007): 582-610.

Cameron, David R. "The Expansion of the Public Economy: A Comparative Analysis." The American Political Science Review 72 (4) (1978): 1243-61. 
Dahl, Robert. Democracy and Its Critics. New Haven, CT: Yale University Press, 1989.

Dawson, Richard E., and James A. Robinson. "Inter-Party Competition, Economic Variables, and Welfare Policies in the American States." The Journal of Politics 25 (2) (1963): 26589.

De Boef, Suzanna. "Modeling Equilibrium Relationships: Error Correction Models with Strongly Autoregressive Data." Political Analysis 9 (1) (2001): 78-94.

De Boef, Suzanna, and Luke Keele. "Taking Time Seriously." American Journal of Political Science 52 (1) (2008): 184-200.

Dickey, David A., and Wayne A. Fuller. "Distribution of the Estimators for Autoregressive Time Series with a Unit Root." Journal of the American Statistical Association 74 (1979): 42731.

Erikson, Robert S., Gerald C. Wright, and John P. McIver. Statehouse Democracy: Public Opinion and Policy in the American States. Cambridge: Cambridge University Press, 1993.

Erikson, Robert S., Gerald C. Wright, and McIver. John P. Statehouse Democracy: Public Opinion and Policy in the American States. Cambridge: Cambridge University Press, 1993.

Fellowes, Matthew C., and Gretchen Rowe. "Politics and the New American Welfare State." American Journal of Political Science 48 (2) (2004): 362-73.

Flavin, Patrick. "Income Inequality and Policy Representation in the American States." American Politics Research 40 (1) (2012): 29-59.

Garand, James. "Explaining Government Growth in the U.S. States." The American Political Science Review 82 (3) (1988): 837-49. 
Garand, James C. "Partisan Change and Shifting Expenditure Priorities in the American States, 1945-1978." American Politics Quarterly 13 (1985): 355-92.

Garrett, Geoffrey. "Capital Mobility, Trade, and the Domestic Politics of Economic Policy." International Organization 49 (4) (1995): 657-87.

—. "Global Markets and National Politics: Collision Course or Virtuous Circle?". International Organization 52 (4) (1998): 787-824.

Genschel, Philipp. "Globalization and the Welfare State: A Retrospective." Journal of European Public Policy 11 (4) (2004): 613-36.

Gilens, Martin. "Inequality and Democratic Responsiveness." Public Opinion Quarterly 69 (5) (2005): 778-96.

—. "'Race-Coding’ and White Opposition to Welfare." American Political Science Review 90 (1996): 593-604.

Gilens, Martin, and Benjamin I. Page. "Testing Theories of American Politics: Elites, Interest Groups, and Average Citizens." Perspectives on Politics 12 (3) (2014): 564-81.

Greene, William. Econometric Analysis. 7th Edition ed. New York: Prentice Hall, 2011.

Grubel, Herbert G., and Peter J. Lloyd. "The Empirical Measurement of Intra- Industry Trade." Economic Record 47 (4) (1971): 494-517.

Grubel, Herbert G. , and Peter J. Lloyd. Intra-Industry Trade, the Theory and Measurement of International Trade in Differentiated Products. London: MacMillan, 1975.

Habermas, Jurgen. "The European Nation-State and the Pressures of Globalization." New Left Journal 235 (1999): 46-57.

Hausmann, Ricardo, Jason Hwang, and Dani Rodrik. "What You Export Matters." Journal of economic growth 12 (1) (2007): 1-25. 
Held, David. Democracy and the Global Order. Cambridge: Polity Press, 1995.

Hellwig, Timothy. "Economic Openness, Policy Uncertainty, and the Dynamics of Government Support." Electoral Studies 26 (4) (2007): 772-86.

Hero, Rodney E. , and Robert R. Preuhs. "Immigration and the Evolving American Welfare State: Examining Policies in the U.S. States." American Journal of Political Science 51 (3) (2007): 498-517.

Huber, Evelyne, Francois Nielsen, Jenny Pribble, and John D. Stephens. "Politics and Inequality in Latin America and the Caribbean." American Sociological Review 71 (6) (2006): 943-63.

Huber, Evelyne, and John D. Stephens. Development and Crisis of the Welfare State : Parties and Policies in Global Markets. Chicago: The University of Chicago Press, 2001.

Jacobs, Lawrence R., and Benjamin I. Page. "Who Influences U.S. Foreign Policy?". The American Political Science Review 99 (1) (2005): 107-23.

Jacobs, Lawrence R., and Robert Y. Shapiro. Politicians Don't Pander: Political Manipulation and the Loss of Democratic Responsiveness. Chicago and London: The University of Chicago Press, 2000.

Katzenstein, Peter J. Small States in World Markets : Industrial Policy in Europe. Cornell Studies in Political Economy. Ithaca, N.Y.: Cornell University Press, 1985.

Kelly, Nathan. J., and Christopher Witko. "Federalism and American Inequality." Journal of Politics 74 (2) (2012): 414-26.

King, Gary, Michael Tomz, and Jason Wittenberg. "Making the Most of the Statistical Analysis." American Journal of Political Science 44 (2000): 341-55. 
Krueger, Brian S., and Paul D. Mueller. "Moderating Backlash: Racial Mobilization, Partisan Coalitions, and Public Policy in the American States." State Politics \& Policy Quarterly 1 (2) (2001): 165-79.

Krugman, Paul R. International Economics: Theory and Policy. India: Pearson Education, 2008. Lax, Jeffrey R., and Justin H. Phillips. "The Democratic Deficit in the States." American Journal of Political Science 56 (1) (2012): 148-66.

Lewis-Beck, Michael S., and Tom W. Rice. "Government Growth in the United States." The Journal of Politics 47 (1) (1985): 2-30.

Lowery, David, and William D. Berry. "The Growth of Government in the United States: An Empirical Assessment of Competing Explanations." American Journal of Political Science 27 (4) (1983): 665-94.

Lowery, David, Thomas Konda, and James Garand. "Spending in the States: A Test of Six Models." Western Political Quarterly 37 (1984): 48-66.

Lynch, Julia. Age in the Welfare State: The Origins of Social Spending on Pensioners, Workers, and Children. Cambridge Studies in Comprative Politics. edited by Margaret Levi New York, NY: Cambridge University Press, 2006.

Manza, Jeff, and Fay Lomax Cook. "A Democratic Polity?: Three Views of Policy Responsiveness to Public Opinion in the United States." American Politics Research 30 (6) (2002): 630-67.

Moller, Stephanie, David Bradley, Evelyne Huber, Francois Nielsen, and John D Stephens. "Determinants of Relative Poverty in Advanced Capitalist Democracies." American Sociological Review 68 (1) (2003): 22-51. 
Monogan, James E. . "The Politics of Immigrant Policy in the Fifty U.S. States from 20052011." Journal of Public Policy 33 (1) (2013): 35-64.

Monroe, Alan D. "Public Opinion and Public Policy, 1980-1993." The Public Opinion Quarterly 62 (1) (1998): 6-28.

Mosley, Layna. "Globalisation and the State: Still Room to Move?". New Political Economy 10 (3) (2005): 355-62.

Owen, Erica, and Dennis P. Quinn. "Does Economic Globalization Influence the Us Policy Mood?: A Study of Us Public Sentiment, 1956-2011." British Journal of Political Science 46 (1) (2016): 95-125.

Pacheco, Julianna. "Using National Surveys to Measure Dynamic U.S. State Public Opinion: A Guideline for Scholars and an Application." State Politics \& Policy Quarterly 11 (4) (2011): 415-439.

Page, Benjamin I., and Robert Y. Shapiro. "Effects of Public Opinion on Policy." American Political Science Review 77 (1) (1983): 175-90.

Persyn, Damiaan, and Joakim Westerlund. "Error Correction Based Cointegration Tests for Panel Data." Stata Journal 8 (2) (2008): 232-41.

Phillips, Peter C. B., and Pierre Perron. "Testing for a Unit Root in Time Series Regression." Biometrika 75 (1988): 335-46.

Piven, Frances Fox. "Globalization, American Politics, and Welfare Policy." Annals of the American Academy of Political and Social Science 577 (2001): 26-37.

Radcliff, Benjamin, and Martin Saiz. "Labor Organization and Public Policy in the American States." Journal of Politics 60 (0) (1998): 113-25. 
—. "Race, Turnout, and Public Policy in the American States." Political Research Quarterly 48 (4) (1995): 775-94.

Ranney, Austin. "Parties in State Politics." Politics in the American States 3 (1976).

Rudra, Nita. "Globalization and the Strengthening of Democracy in the Developingworld." American Journal of Political Science 49 (4) (2005): 704-30.

Sharkansky, Ira and Richard I. Hofferbert. "Dimensions of State Politics, Economics, and Public Policy." The American Political Science Review 63 (3) (1969): 867-79.

Soss, Joe, Sanford Schram, Thomas Vartanian, and Erin O'Brien. "Setting the Terms of Relief: Explaining State Policy Choices in the Devolution Revolution." American Journal of Political Science 45 (2) (2001): 378-95.

Stimson, James A., Michael B. Mackuen, and Robert S. Erikson. "Dynamic Representation." American Political Science Review 89 (3) (1995): 543-65.

Stimson, James. A. . Public Opinion in America: Moods, Cycles, and Swings. Boulder, CO: Westview Press, 1991.

Story, Louise. "As Companies Seek Tax Deals, Governments Pay High Price." New York Times, Decemer 1 2012. Accessed on January 13, 2016. http://www.nytimes.com/2012/12/02/us/how-local-taxpayers-bankrollcorporations.html?pagewanted=all\&_r $=0$

Swank, Duane. "Globalisation, Domestic Politics, and Welfare State Retrenchment in Capitalist Democracies." Social Policy and Society 4 (2) (2005): 183-95.

Tiebout, Charles M. "A Pure Theory of Local Expenditures." The journal of political economy (1956): 416-24. 
Volden, Craig. "The Politics of Competitive Federalism: A Race to the Bottom in Welfare Benefits?". American Journal of Political Science (2002): 352-63.

Wagner, Adolph. Finanzwissenschaft Pt I. Leipzig: C.F. Winter, 1877.

Waltz, Kenneth N. "Globalization and Governance." PS: Political Science and Politics 32 (4) (1999): 693-700.

Weingast, Barry R. "The Economic Role of Political Institutions: Marketpreserving Federalism and Economic Development." Journal of Law, Economics, and Organization 11 (1995): $1-31$

—. "The Economic Role of Political Institutions: Market-Preserving Federalism and Economic Development." Journal of Law, Economics, \& Organization 11 (1) (1995): 131.

Westerlund, Joakim. "Testing for Error Correction in Panel Data." Oxford Bulletin of Economics and Statistics 69 (6) (2007): 709-48.

Wright, Gerald C., Robert S. Erikson, and John P. McIver. "Measuring State Partisanship and Ideology with Survey Data." The Journal of Politics 47 (2) (1985): 469-89.

Wright, Gerald C., Jr., Robert S. Erikson, and John P. McIver. "Public Opinion and Policy Liberalism in the American States." American Journal of Political Science 31 (4) (1987): 980-1001. 


\section{Endnotes}

${ }^{1}$ Author names are listed in alphabetical order.

${ }^{2}$ Whereas early research using demographic proxies for opinion data found little connection between opinion and public policy (e.g. Sharkansky and Hofferbert 1969), the vast majority of scholarship over the past few decades points to a robust connection (Burstein, 2010; 2003). This linkage has been considered over both the long and short term, with Wright, Erikson, and McIver's (1985; 1987; 1993) path breaking work notably showing that the most liberal polities tend to have the most liberal policies and with others (Stimson, MacKuen and Erikson 1995; Page \& Shapiro 1983) showing that short term opinion shifts precede congruent policy changes. Not only temporally robust, the opinion-policy linkage generally holds across diverse measurement decisions, with indicators of specific and general political opinions and variously conceived policy outcomes generally confirming the linkage (e.g. Brace, et al. 2002). Although this literature focuses on the United States, and particularly the American states, recent scholarship employing cross-national data also supports the view that voters' political preferences tend to map with policy outcomes in developed democracies (Brooks and Manza 2006a; 2006b).

${ }^{3}$ As importantly, states have a wide range of citizen ideologies and largely control the nature of state policy and public spending (Garand, 1985; Berry, Ringquist, Fording, \& Hanson, 1998; Kelly \& Witko, 2012).

${ }^{4}$ This can be seen as an extension of typical race-to-the-bottom theory of market preserving federalism that suggests that many U.S. or foreign firms will move to the American states with the lowest wages, taxes, and regulations, thus pressuring state spending downward through inter-state competition (Tiebout 1956; Weingast 1995; Volden 2002). Global competition, compared to state-to-state competition, is special only as a matter of degree. But the difference in degree is significant, as the variance between U.S. states' environmental, tax, and wage conditions and developing countries' conditions is dramatically wider than the variance between U.S states.

${ }^{5}$ As Mosely plainly reviews this perspective, “[g]overnments must sell their policy not only to voters, but also to international investors” (2000, 357).

${ }^{6}$ Readers should consider the possibility that a null interaction term (public opinion * globalization) stems from poor measurement rather than the mechanisms outlined in the RTM theory, given that noisy measures inflate standard errors and often lead to null results.

${ }^{7}$ As a robustness check, we use \% overall state expenditure/gross state product and \% state welfare expenditure/gross state product and the logarithm of spending as alternative dependent variables. Additionally, we use the State and Local Government Finance Report of the U.S. Census to combine state and local government total spending and state and local welfare spending. The implications for the hypotheses are very similar to the results presented in this paper and support the same key conclusions of no significant attenuation of the opinion-policy connection in highly globalized states.

${ }^{8}$ For our general liberal opinion measure we largely follow Stimson, MacKuen, Erikson (1994). “These real preferences, what we have called 'policy mood,' (Stimson 1991) are standing predispositions toward the role of government. Global public opinion is at the highly generalized level at which we believe typical citizens - not C-SPAN junkies- approach government.” (30)....”much of public opinion in American politics can be understood as generalized views toward government itself.” (31). And as Manza and Cook point out, the focus on general policy mood avoids the low policy information on the part of the public (2002: 637).

${ }^{9}$ As a robustness check, we replace our dependency ratio with \% older population (over 65 years old) and \% young population (under 18 years old), individually, and the models show very similar results. 
${ }^{10}$ We used the Clarify program in Stata 12.0 to graph all our figures (King, et al. 2000).

${ }^{11}$ We also ran a series of models using TANF cash benefits for a family of three as the dependent variable. This variable has two notable problems, however, which relegates its use to a robustness check rather than as a core part of the analysis. Welfare generosity data are available for only about half the time series and this measure often does not vary much within the same state for many years at a time. Nonetheless, across the models, in no case is the interaction term statistically significant; again, the opinion liberalism - public policy linkage is not weaker in states with high levels of global trade. 